\title{
Screening for B cell, $T$ cell and natural killer cell defects among children with methylmalonic and propionic acidemias
}

\author{
Shereen M. Reda', Heba S. Elabd², Rasha H. El-Owaidy ${ }^{1 *}$ (D, Ahmad M. Salah El Din ${ }^{3}$ and Mahmoud A. Hassan ${ }^{3}$
}

\begin{abstract}
Background: Patients with methylmalonic acidemias (MMAs) and propionic acidemias (PAs) were noticed to suffer recurrent infections with high morbidity and mortality during infections. Neutropenia, impaired phagocytic chemotaxis, low levels of IgG, and depletion of B and T cells in patients with PA and MMA have been previously reported, but relevant studies were limited and based on case reports or small cohorts, with contradictory results. We sought to evaluate B cells, T cells, and natural killer (NK) cells in children with MMA and PA and investigate the impact of metabolic disease control on the studied immunological parameters. Thirty patients (23 MMAs and 7 PAs) were enrolled in a cross-sectional study. Patients were subjected to clinical evaluation, complete blood count, blood gases, serum immunoglobulin levels, candida intradermal testing, and lymphocyte subset flow cytometric enumeration.
\end{abstract}

Results: Patients' ages ranged between 6 and 86 months (mean 37.93 \pm 23.2 SD). BCG scar was elicited in 24/26 (92.3\%) of vaccinated patients. Candida test was positive in 12 (85.7\%) out of 14 tested patients. Four patients had neutropenia (13.3\%), 1 had lymphopenia (3.3\%), 17 had low absolute CD19+ counts (56.7\%), 5 had low absolute CD27+ counts (16.7\%), 14 had low CD3+ counts (46.7\%), 9 had low CD4+ counts (30\%), 8 had low CD8+ counts (26.7\%), 12 had decreased CD4/CD8 ratio (40\%), and 8 had low CD56+ counts (26.7\%). All patients had normal serum immunoglobulins. Metabolically controlled and uncontrolled cases were comparable in terms of their candida test results and lymphocyte subsets.

Conclusion: Patients with MMA or PA are prone to neutropenia, decreased B and T cells with low CD4+/CD8+ ratio, and decreased NK cells, yet with normal serum immunoglobulins and candida intradermal test results. We could not find a relation between the immunological results and the degree of metabolic disease control.

Keywords: Organic acidemia, Pediatrics, Adaptive, Infections, Screening

\section{Background}

Methylmalonic acidemias (MMAs) and propionic acidemias (PAs) comprise a group of congenital disorders of branched-chain amino acid metabolism leading to their accumulation in the body fluids [1]. Patients with organic acidemia suffer both recurrent infections and recurrent hospital admissions with higher morbidity and mortality during these infections compared to normal subjects. Thus, an association has been suspected

\footnotetext{
* Correspondence: rasha2hasan@gmail.com

${ }^{1}$ Department of Pediatrics, Allergy and Immunology Unit, Faculty of

Medicine, Children's Hospital, Ain-Shams University, Abbassya Square, Cairo

11566, Egypt

Full list of author information is available at the end of the article
}

between organic acidemia and immunodeficiencies. Neutropenia, impaired phagocytic chemotaxis, low levels of IgG, and depletion of $\mathrm{B}$ and $\mathrm{T}$ cells in patients with PA and MMA have been previously reported [2, 3]. A link has been suspected between decreased extracellular $\mathrm{PH}$ and lymphocyte number and function [4].

Previous studies investigating immune status of those patients are limited and based on case reports or small cohorts, with contradictory results. The relation of immune dysfunction to the metabolic status and the presence of acidosis is still unclear [5]. Proper evaluation of the immune status of those patients is of utmost importance aiming to provide preventive measures and early appropriate management of infections in order to 
decrease morbidity, mortality, and health care costs. Thus, our study was designed to assess B cells, $\mathrm{T}$ cells, and natural killer (NK) cells in pediatric patients with MMA or PA and their relation to the infection profile and the metabolic disease control.

\section{Methods}

This cross-sectional study was carried out at the Genetic Unit, Children's Hospital, Ain-Shams University, during the period from February 2015 to April 2017.

\section{Study subjects}

The study included all the available 30 pediatric cases of confirmed MMA or PA patients. Twenty-three cases had MMA, and the other 7 cases had PA with a female predominance in the form of female-to-male ratio of 8:7 and age ranging from 6 to 86 months with a mean of 37.93 months. Twenty-seven patients (90\%) were of consanguineous parents. Patients receiving steroids or other immunosuppressive therapy at the time of enrollment and those having secondary immunodeficiency (i.e., HIV infection, nephrotic syndrome, and sickle cell disease) were excluded from the study. All cases were receiving oral bicarbonate, L-carnitine, and protein restricted diet ( 0.5 to $1.5 \mathrm{gm} / \mathrm{kg}$ per day; free or low protein milk, e.g., XMTVI and Duocal protein-free milk).

\section{Study methods}

All patients included in the study were subjected to detailed history taking including onset, course, duration of the metabolic disease, age at metabolic disease onset, age of onset of infection, sites of recurrent infections, duration of infection, frequency of hospitalization, and average duration of antibiotic use at time of infection. Patients were screened for the presence of one or more of the warning signs for primary immunodeficiency [6] including four or more new ear infections within 1 year, two or more serious sinus infections within 1 year, two or more pneumonias within 1 year, two or more deepseated infections including septicemia, recurrent deep skin or organ abscesses, persistent oral or skin fungal infections, infections that do not respond to more than 2 months of standard antibiotics, need for intravenous antibiotics to clear infections, failure to thrive or growth retardation, and/or family history of primary immunodeficiency.

Family history including parents' consanguinity, recurrent infections, diagnosed primary immunodeficiency, or previous sibling deaths was documented. Detailed systemic examination was performed including site, type, and severity of infection, and presence of organomegaly and lymphadenopathy, in addition to weight and height assessment in relation to normal percentiles of age [7].

\section{Laboratory investigations In vivo test}

Manually prepared candida intradermal skin testing (intradermal injection of $0.1 \mathrm{ml}$ of $1 / 1000$ dilution for patients $\geq 6$ years and $1 / 100$ if $<6$ years) was performed in patients with lymphocytic count $>1500 /$ ul, to screen for $\mathrm{T}$ cell function. The appearance of an induration with a diameter of $\geq 5 \mathrm{~mm}, 48-72 \mathrm{~h}$ after the injection, indicated intact $\mathrm{T}$ cell function [8]. Although none of the 30 enrolled patients had absolute lymphocyte count (ALC) less than $1500 / \mu \mathrm{l}$, only 14 patients agreed to do the candida intradermal skin test.

\section{In vitro tests}

All enrolled patients were subjected to the following laboratory assessments:

- Complete blood counts using Beckman-Coulter Gen.S system 2, USA, and samples were smeared and stained with Leishman's stain for assessment of differential white blood cell counts.

- Flow cytometric enumeration for percentages and absolute counts of the following lymphocytes subsets: CD19+ and CD27+ B lymphocytes, CD3+, $\mathrm{CD} 3+\mathrm{CD} 4+$, and $\mathrm{CD} 3+\mathrm{CD} 8+\mathrm{T}$ cells in addition to CD3-CD56+ NK cells. They were measured in peripheral blood samples using Coulter XL-flow Cytometer (Beckman, USA). Results of differential white cell counts and lymphocyte subsets were compared to age-related reference ranges [9].

- Total serum immunoglobulins were measured using quantitative nephelometry for IgA, IgG, and IgM (using MININEPH nephelometer, Binding Site, UK) and enzymatic immunoassay by ELISA for IgE (using VersaMax ${ }^{\text {Tm }}$ ELISA kits). Results of Immunoglobulins were compared to age-related reference ranges [10].

- Venous blood gases were tested at enrollment. Venous blood samples in heparinized syringes were assayed using the ABL80 FLEX analyzer-BASIC version, Radiometer Instruments, USA.

- Serum albumin level was measured using Synchron CX-9 auto analyzer, Beckman Instruments Inc., Fullerton, CA, USA.

Degree of control of metabolic disease of the patients was determined according to clinical evaluation and blood gas results at the time of enrollment. Uncontrolled cases were defined by the presence of symptoms of the organic acidemia (e.g., poor feeding, vomiting, floppiness, lethargy, or coma) and venous blood $\mathrm{pH}<7.35$. Controlled cases were defined as stable clinical condition and venous blood $\mathrm{pH}$ not less than 7.35 at the time of enrollment. 


\section{Statistical methods}

Statistical software package (SPSS) (V.15.0, Echosoft Corp, USA, 2006) was used for data analysis. Data were represented as mean values and standard deviation (SD) for quantitative measures or number and percentage for categorized data. Comparisons of several means were done by using one-way analysis of variance (ANOVA). Comparison between two means was done by using paired $t$ test. Comparison of different variables in various groups was done using Student's $t$ test and the MannWhitney test for normal and non-parametric variables, respectively. Chi-square $\left(\chi^{2}\right)$ test was used to compare the frequency of qualitative variables among different groups. For all tests, probability $(p)$ values $\leq 0.05$ were considered significant.

\section{Results}

Out of the 30 enrolled patients, 23 (76.7\%) had MMA and $7(23.3 \%)$ had PA. They were $16(53.5 \%)$ boys and $14(46.7 \%)$ girls. The patients' age ranged from 6 to 86 months with a mean of $37.9 \pm 23.2$ SD. According to clinical evaluation (concerning conscious level, vomiting, anorexia and general activity, growth charts) and venous blood gas results at enrollment, $12(40 \%)$ patients were found to have uncontrolled metabolic disease while the remaining 18 (60\%) patients had controlled disease.
Patients' demographic and clinical parameters and blood gas results are shown in Tables 1 and 2 .

Chest infections $(n=15,50 \%)$ were the most commonly encountered among enrolled patients in the form of upper respiratory tract infection $(n=14)$ and pneumonia $(n=5)$ followed by GIT infections in the form of recurrent gastroenteritis $(n=11,36.7 \%)$. The duration of infections ranged between 4 and 8 days with a mean \pm SD of $6.6 \pm 1.22$ days. None of the enrolled patients had recurrent skin infections, septicemia, or recurrent herpes infection.

Concerning the frequency of each of the 10 warning signs for primary immunodeficiency among the studied patients, the most commonly encountered signs were failure to gain weight $(n=20,66.7 \%)$ and the need for intravenous antibiotic to clear infection $(n=24,80 \%)$. Only two patients gave history of two or more pneumonia per year. Others warning signs of immunodeficiency were not met among our studied patients.

Before enrollment in the study, 26 (86.7 \%) patients received BCG vaccine. Out of these 26 vaccinated patients, 24 (92.3\%) had evident BCG scar.

Table 3 shows the blood picture counts and serum albumin of enrolled patients. Four patients (13.33\%) had neutropenia at the time of enrollment (absolute neutrophil count $(\mathrm{ANC})<1500 / \mu \mathrm{l})$, one patient $(3.33 \%)$ had lymphopenia, and one (3.33\%) had thrombocytopenia

Table 1 Demographic and clinical characteristics of enrolled patients

\begin{tabular}{|c|c|c|}
\hline Parameter & & Results \\
\hline \multirow[t]{2}{*}{ Diagnosis (no. (\%)) } & MMA & $23(76.7 \%)$ \\
\hline & PA & $7(23.3 \%)$ \\
\hline \multirow[t]{2}{*}{ Sex (no. (\%)) } & Male & $16(53.3 \%)$ \\
\hline & Female & $14(46.7 \%)$ \\
\hline \multirow[t]{2}{*}{ Age (mo.) } & Mean \pm SD & $37.93 \pm 23.20$ \\
\hline & Range & $6-86$ \\
\hline \multirow[t]{2}{*}{ Weight (centile) } & Mean \pm SD & $24.73 \pm 27.15$ \\
\hline & Range & $3-75$ \\
\hline \multirow[t]{2}{*}{ Height (centile) } & Mean \pm SD & $9.40 \pm 15.53$ \\
\hline & Range & $3-75$ \\
\hline \multirow[t]{2}{*}{ Age at metabolic disease onset (mo.) } & Mean \pm SD & $6.59 \pm 4.58$ \\
\hline & Range & $0.1-19$ \\
\hline \multirow[t]{2}{*}{ Age of onset of infection (mo.) } & Mean \pm SD & $6.24 \pm 4.41$ \\
\hline & Range & $0-19$ \\
\hline \multirow[t]{2}{*}{ Frequency of hospitalization due to infection/year } & Mean \pm SD & $1.80 \pm 0.76$ \\
\hline & Range & $1-3$ \\
\hline \multirow[t]{2}{*}{ Average duration of antibiotics use during infection (days) } & Mean \pm SD & $6.13 \pm 1.22$ \\
\hline & Range & $4-9$ \\
\hline \multirow[t]{2}{*}{ Control of the metabolic disease (controlled/uncontrolled) (no. (\%)) } & Controlled & $18(60.0 \%)$ \\
\hline & Uncontrolled & $12(40.0 \%)$ \\
\hline
\end{tabular}


Table 2 Results of venous blood gases with anion gap for enrolled patients

\begin{tabular}{lll}
\hline & Mean \pm SD & Range \\
\hline $\mathrm{pH}(7.35-7.45)$ & $7.37 \pm 0.11$ & $7.1-7.53$ \\
$\mathrm{BE}(-2$ to $+2 \mathrm{mEq} / \mathrm{l})$ & $-0.60 \pm 2.26$ & $-8.5-3.9$ \\
$\mathrm{HCO}$ (35-45) & $21.12 \pm 2.61$ & $15.8-26.7$ \\
Anion gap (3-11) & $16.80 \pm 2.27$ & $13-21$ \\
\hline
\end{tabular}

BE base excess, $\mathrm{HCO} 3$ bicarbonate

compared to their age-related reference ranges. None of the enrolled patients had albumin levels below $3.5 \mathrm{gm} / \mathrm{dl}$

Relative and absolute counts of the studied lymphocyte subsets were variably affected among the studied patients. Seventeen patients had low absolute B cell (CD19+) counts (56.7\%), 5 had low absolute memory B cell $(\mathrm{CD} 27+)$ counts $(16.7 \%), 14$ had low CD3+ counts (46.7\%), 9 had low CD4+ counts (30\%), 8 had low CD $8+$ counts (26.7\%), 12 had decreased CD4/CD8 ratio (40\%), and 8 had low CD56+ counts (26.7\%). Results are depicted in Table 4.

There was only one lymphopenic patient with absolute lymphocyte count (ALC) of 1700/ul. T cell function was tested using the candida intradermal skin test which was done in 14 out of 30 enrolled patients, while the remaining 16 patients refused to do the test. Among the tested 14 patients, $12(85.7 \%)$ gave positive results, with a mean induration diameter (in $\mathrm{mm}$ ) of $8.2 \pm 2.1 \mathrm{SD}$ (range $5-12 \mathrm{~mm}$ ). The remaining two patients $(14.3 \%$ ) who gave negative results had normal absolute counts of the studied lymphocyte subsets.

For assessment of B cell function, serum immunoglobulins (Ig) were measured and none of the enrolled patients showed low IgA, IgG, IgM, or IgE, according to their agerelated reference ranges. Mean levels of serum immunoglobulins and their ranges are depicted in Table 5.

Table 3 Basic laboratory investigations of the studied patients

\begin{tabular}{lll}
\hline Parameters & \multicolumn{2}{l}{ Absolute value } \\
\cline { 2 - 3 } & Range & Mean \pm SD \\
\hline WBCs $\left(\times 10^{3} / \mu l\right)$ & $3.9-17.9$ & $9.77 \pm 3.94$ \\
ANC $\left(\times 10^{3} / \mu l\right)$ & $0.5-10.8$ & $3.66 \pm 2.75$ \\
ALC $\left(\times 10^{3} / \mu l\right)$ & $1.7-10.6$ & $5.17 \pm 2.08$ \\
AMC $\left(\times 10^{3} / \mu l\right)$ & $0.2-1.7$ & $0.77 \pm 0.36$ \\
AEC $\left(\times 10^{3} / \mu l\right)$ & $0-1$ & $0.20 \pm 0.25$ \\
ABC $\left(\times 10^{3} / \mu l\right)$ & $0-0.3$ & $0.07 \pm 0.08$ \\
HGB $(\mathrm{g} / \mathrm{dl})$ & $7.5-12.9$ & $10.21 \pm 1.52$ \\
MCV $(\mathrm{fl})$ & $56-87.5$ & $74.47 \pm 7.88$ \\
Albumin $(\mathrm{g} / \mathrm{dl})$ & $3.5-5.4$ & $4.58 \pm 0.53$
\end{tabular}

$A B C$ absolute basophil counts, $A E C$ absolute eosinophil counts, $H G B$ hemoglobin, $A L C$ absolute lymphocyte counts, $A M C$ absolute monocyte counts, $M C V$ mean corpuscular volume, $A N C$ absolute neutrophil counts, WBCs white blood cells
In view of clinical condition and blood gas results at enrollment, patients with controlled metabolic disease $(n=18)$ were comparable with those with the uncontrolled disease $(n=12)$ in terms of clinical parameters, infection profile, and studied lymphocyte subsets (Tables 6 and 7). Also, candida intradermal test positivity ( $44 \%$ versus $50 \%, p=0.765$ ) and induration diameters (mean \pm SD $7.94 \pm 2.51$ versus $8.58 \pm 1.56, p=0.591$ ) were comparable in both groups, respectively).

\section{Discussion}

Compared to normal subjects, patients with organic acidemia were observed to have unusually recurrent and/or severe infections [5]. In our series, chest infections $(50 \%)$ were the most commonly observed, followed by GIT infections (36.7\%). Similar observations were previously reported by El Essa et al., in their retrospective study on 38 patients with PA [11]. Failure to thrive and requirement of parenteral antibiotics to clear infections were observed in $66.7 \%$ and $80 \%$ of our patients, respectively. Although these two signs are among the 10 warning signs for immunodeficiency, yet in our study, these signs should be interpreted cautiously as they might be caused by features of the metabolic disease itself including anorexia, repeated vomiting, mental retardation, and protein restriction [12].

Clinical examination of the studied patients revealed the presence of BCG scar in 24 out of 26 vaccinated patients. The two patients with failed BCG scar formation both had MMA, had positive results for candida intradermal skin test, and had good control of metabolic disease at enrollment. According to $C D C$ fact sheets for tuberculosis and BCG vaccine [13], 10\% of healthy BCGvaccinated children might fail to form a scar, making our results comparable to the BCG response in the general population.

In the current study, three patients had neutropenia and one patient had mild lymphopenia. In the study of Wong et al. [2] on three patients with MMA, there was severe pancytopenia with consequent fatal gram-negative septicemia, candidiasis, and Pneumocystis jirovecii pneumonia. Moreover, significant defects in neutrophil functions were reported in patients with organic acidemias especially during the attacks of acidosis and ketotic hyperglycemia $[14,15]$. The accumulation of organic acid metabolites was found to induce transient inhibition of bone marrow stem cell growth and maturation, with granulopoiesis most commonly to be affected [16].

Our study revealed variable affection of the relative and absolute counts of the studied lymphocyte subsets. The known associated oxidative stresses and energy metabolism impairment with organic acidemias might be responsible for the suppression of lymphocyte production [3]. El Essa et al. reported decrease in $\mathrm{B}$ and $\mathrm{T}$ lymphocyte 
Table 4 Flow-cytometric results of B and T lymphocyte subsets and NK cells in the studied patients

\begin{tabular}{|c|c|c|c|c|}
\hline \multirow{2}{*}{$\frac{\text { T lymphocyte subsets }}{\text { CD3+ (\%) }}$} & \multirow{2}{*}{$\frac{\text { Mean } \pm \text { SD }}{68.13 \pm 10.62}$} & \multirow{2}{*}{$\begin{array}{l}\text { Range } \\
43.5-84.9\end{array}$} & \multicolumn{2}{|c|}{ Interpretation } \\
\hline & & & Normal & $26(86.7 \%)$ \\
\hline & & & Low & $4(13.3 \%)$ \\
\hline \multirow[t]{2}{*}{ CD3+ (absolute) cells $/ \mathrm{mm}^{3}$} & $2469.63 \pm 1921.90$ & $414-7668$ & Normal & $16(53.3 \%)$ \\
\hline & & & Low & $14(46.7 \%)$ \\
\hline \multirow[t]{2}{*}{ CD4+ (\%) } & $57.11 \pm 15.33$ & $24.9-83.3$ & Normal & $29(96.7 \%)$ \\
\hline & & & Low & $1(3.3 \%)$ \\
\hline \multirow[t]{2}{*}{ CD4+ (absolute) cells $/ \mathrm{mm}^{3}$} & $2119.67 \pm 1654.29$ & $190-6073$ & Normal & $21(70.0 \%)$ \\
\hline & & & Low & $9(30.0 \%)$ \\
\hline \multirow[t]{2}{*}{ CD8+ (\%) } & $35.23 \pm 13.47$ & $13.6-66.7$ & Normal & $29(96.7 \%)$ \\
\hline & & & Low & $1(3.3 \%)$ \\
\hline \multirow[t]{2}{*}{ CD8+ (absolute) cells $/ \mathrm{mm}^{3}$} & $1107.37 \pm 817.89$ & $257-2838$ & Normal & $22(73.3 \%)$ \\
\hline & & & Low & $8(26.7 \%)$ \\
\hline \multirow[t]{2}{*}{ CD4/CD8 ratio } & $2.11 \pm 1.48$ & $0.37-6.12$ & Normal & $18(60.0 \%)$ \\
\hline & & & Low & $12(40.0 \%)$ \\
\hline \multirow[t]{2}{*}{ CD56+ (\%) } & $9.15 \pm 5.86$ & $2.22-23.7$ & Normal & $25(83.3 \%)$ \\
\hline & & & Low & $5(16.7 \%)$ \\
\hline \multirow[t]{2}{*}{ CD56+ (absolute) cells $/ \mathrm{mm}^{3}$} & $393.30 \pm 453.79$ & $18-2160$ & Normal & $22(73.3 \%)$ \\
\hline & & & Low & $8(26.7 \%)$ \\
\hline \multirow[t]{2}{*}{ CD19+ (\%) } & $7.90 \pm 3.90$ & $2.18-14.3$ & Normal & $1(3.3 \%)$ \\
\hline & & & Low & $29(96.7 \%)$ \\
\hline \multirow[t]{2}{*}{ CD19+ (absolute) cells $/ \mathrm{mm}^{3}$} & $414.15 \pm 246.01$ & $37.06-930$ & Normal & $13(43.3 \%)$ \\
\hline & & & Low & $17(56.7 \%)$ \\
\hline \multirow[t]{2}{*}{ CD27+ (\%) } & $33.61 \pm 17.11$ & $8-65$ & Normal & $4(13.3 \%)$ \\
\hline & & & High & $26(86.7 \%)$ \\
\hline \multirow[t]{2}{*}{ CD27+ (absolute) cells $/ \mathrm{mm}^{3}$} & $134.64 \pm 103.57$ & $10.98-413.54$ & Normal & $25(83.3 \%)$ \\
\hline & & & Low & $5(16.7 \%)$ \\
\hline
\end{tabular}

$C D$ cluster of differentiation, \% percentage, $M M A$ methylmalonic acidemia, $P A$ propionic acidemia, $S D$ standard deviation

subsets with decreased $\mathrm{CD} 4 / \mathrm{CD} 8$ ratio in three PA patients during the metabolic attack [11]. Similar observations were also reported by Wong et al. in their studied three MMA patients [2]. In contrast, another study including four MMA patients (3-6 years of age) found that $\mathrm{T}$ lymphocyte numbers were normal in three of them [15]. Variable results in different studies might be attributed to several factors including the sample size, duration of the metabolic disease, residual enzyme activity, and the exact timing of patients' evaluation whether during or in between the acidotic episodes. All our patients were on

Table 5 Total serum immunoglobulin levels of enrolled patients

\begin{tabular}{lll}
\hline Serum lgs levels & Mean \pm SD & Range \\
\hline $\lg A(\mathrm{mg} / \mathrm{dl})$ & $92.63 \pm 54.72$ & $17-195$ \\
$\lg G(\mathrm{mg} / \mathrm{dl})$ & $908.40 \pm 341.10$ & $314-1565$ \\
$\lg M(\mathrm{mg} / \mathrm{dl})$ & $100.80 \pm 65.11$ & $16-254$ \\
$\lg E(\mathrm{IU} / \mathrm{ml})$ & $37.20 \pm 24.38$ & $7-87$
\end{tabular}

Igs immunoglobulins management strategy despite that many were uncontrolled.

Although B cell counts were low in some of our patient, yet total serum immunoglobulins were normal in all cases, indicating preserved B cell function. Alizadeh et al. found normal values of immunoglobulins among 31 studied patients with organic acidemias except for only 2 patients who had low IgM levels [5]. In another study, marginal decrease in serum IgG level in two MMA patients with normal serum IgA and IgM concentrations was observed [15]. Low IgG levels were also reported in patients with PA [3]. Better evaluation of $B$ cell function necessitates the assessment of specific antibody response to vaccines which was lacking in our work. Protective rubella antibody titers were found in three patients with MMA, while only one patient had undetectable titer [15]. On the other hand, very low levels of anti-tetanus IgG and antidiphtheria IgG were observed in two patients with maple syrup urine disease despite receiving the 
Table 6 Comparison between controlled and uncontrolled patients regarding their clinical parameters

\begin{tabular}{|c|c|c|c|c|c|}
\hline \multirow[t]{2}{*}{ Variables } & & \multirow{2}{*}{$\begin{array}{l}\text { Controlled } \\
N=18\end{array}$} & \multirow{2}{*}{$\begin{array}{l}\text { Uncontrolled } \\
N=12\end{array}$} & \multicolumn{2}{|c|}{ Independent $t$ test } \\
\hline & & & & $t / x^{2 *}$ & $p$ value \\
\hline \multirow[t]{2}{*}{ Age (mo.) } & Mean \pm SD & $34.78 \pm 23.50$ & $42.67 \pm 22.91$ & 0.91 & 0.371 \\
\hline & Range & $10-86$ & $6-72$ & & \\
\hline \multirow[t]{2}{*}{$\operatorname{Sex}(n(\%))$} & Female & $11(61.1 \%)$ & $5(41.7 \%)$ & 1.094 & $0.296^{*}$ \\
\hline & Male & 7 (38.9\%) & $7(58.3 \%)$ & & \\
\hline \multirow[t]{2}{*}{ Weight $(p)$} & Mean \pm SD & $21.78 \pm 26.20$ & $29.17 \pm 29.09$ & 0.724 & 0.475 \\
\hline & Range & $3-75$ & $3-75$ & & \\
\hline \multirow[t]{2}{*}{ Height $(p)$} & Mean \pm SD & $6.28 \pm 5.63$ & $14.08 \pm 23.39$ & 1.369 & 0.182 \\
\hline & Range & $3-25$ & $3-75$ & & \\
\hline \multirow[t]{2}{*}{ Age at metabolic disease onset } & Mean \pm SD & $6.29 \pm 4.65$ & $7.00 \pm 4.65$ & 0.407 & 0.687 \\
\hline & Range & $0.3-19$ & $0-12$ & & \\
\hline \multirow[t]{2}{*}{ Age of onset of infection (mo.) } & Mean \pm SD & $5.72 \pm 4.87$ & $6.59 \pm 3.83$ & 0.518 & 0.608 \\
\hline & Range & $0.03-19$ & $0.1-12$ & & \\
\hline \multirow[t]{2}{*}{ Average duration of antibiotics use at time of infection (days) } & Mean \pm SD & $6.00 \pm 0.84$ & $5.75 \pm 1.06$ & -0.721 & 0.477 \\
\hline & Range & $4-7$ & $4-7$ & & \\
\hline \multirow{3}{*}{$\begin{array}{l}\text { Frequency of hospitalization } \\
\text { due to infection/year }\end{array}$} & Once & $8(44.4 \%)$ & $4(33.3 \%)$ & 0.833 & $0.659^{*}$ \\
\hline & Twice & $6(33.3 \%)$ & $6(50.0 \%)$ & & \\
\hline & Thrice & $4(22.2 \%)$ & $2(16.7 \%)$ & & \\
\hline \multirow[t]{2}{*}{ Average duration of infection (days) } & Mean \pm SD & $6.67 \pm 1.19$ & $6.50 \pm 1.31$ & -0.361 & 0.721 \\
\hline & Range & $4-8$ & $4-8$ & & \\
\hline
\end{tabular}

mo. months, $N$ number, $p$ percentile, SD standard deviation, $\%$ percentage

*Chi-square test

appropriate vaccinations. However, no significant association was found between the evaluated parameters and history of recurrent admissions, recurrent infections, and type of their disease [5].

As a simple and reliable screening tool for $\mathrm{T}$ cell function [17], we performed the intradermal candida skin test in $14(46.7 \%)$ of our patients and $85 \%$ of them had positive results. The remaining two patients who gave negative results did not have otherwise significant abnormality in the performed immunological evaluation. In healthy children, candida intradermal test usually gives positive results in $60-85 \%$ of tested individuals $[18,19]$. Thus, our findings point to the absence of major defect in $\mathrm{T}$ cell function among the tested patients.

Regarding NK cells (CD56+), our study showed that there was a decrease in CD56+ absolute counts in eight of our patients, six of them were MMA and other two were PA. To the best of our knowledge, natural killer cells have not been previously assessed among patients with organic acidemias. Although our study shows affection in NK numbers and percentages, yet further studies are required to investigate NK cell degranulation and cytotoxicity among patients with organic acidemias, in view of their clinical condition and predisposition to infection.
In our study, when patients were classified according to the control of their metabolic disease at the time of enrollment, both controlled and uncontrolled groups were comparable in the studied lymphocyte subsets, candida test induration diameters, and immunoglobulin profile. However, previous studies that have performed in vitro lymphocyte proliferation tests reported significant suppressive effect of accumulating organic acids on DNA synthesis and lymphocyte proliferation in response to concanavalin A, pokeweed mitogen, and phytohaemagglutinin [3, 20]. Different methods for evaluation (in vitro/in vivo) and variation in severity and duration of disease and variation of the residual activity of the affected enzyme might be responsible for the different results of different reports. Thus, further follow-up of those patients is warranted to assess the effect of prolonged accumulation of organic acids on adaptive immune response, in addition to their assessment during periods of uncontrolled metabolic disease.

\section{Conclusion}

Patients with MMA or PA had variable decrease in relative and absolute counts of $\mathrm{B}$ and $\mathrm{T}$ lymphocyte subsets and NK cells but with normal levels of serum immunoglobulins and intact intradermal candida test response. The degree of control of metabolic disease at enrollment 
Table 7 Variation of T and B lymphocyte subsets and NK cells among metabolically controlled and uncontrolled patients

\begin{tabular}{|c|c|c|c|c|c|c|c|}
\hline \multirow[t]{2}{*}{ T lymphocyte subsets } & & \multicolumn{2}{|c|}{ Controlled $(N=18)$} & \multicolumn{2}{|c|}{ Uncontrolled $(N=12)$} & \multicolumn{2}{|c|}{ Comparison } \\
\hline & & $\bar{N}$ & $\%$ & $N$ & $\%$ & $x^{2}$ & $\begin{array}{l}p \\
\text { value }\end{array}$ \\
\hline \multirow[t]{2}{*}{$\mathrm{CD} 3+(\%)$} & Normal & 15 & 83.3 & 11 & 91.7 & 0.433 & 0.511 \\
\hline & Low & 3 & 16.7 & 1 & 8.3 & & \\
\hline \multirow[t]{2}{*}{$\mathrm{CD} 3+$ count cells $/ \mathrm{mm}^{3}$} & Normal & 9 & 50.0 & 7 & 58.3 & 0.201 & 0.654 \\
\hline & Low & 9 & 50.0 & 5 & 41.7 & & \\
\hline \multirow[t]{2}{*}{ CD4+ (\%) } & Normal & 17 & 94.4 & 12 & 100.0 & 0.690 & 0.406 \\
\hline & Low & 1 & 5.6 & 0 & 0.0 & & \\
\hline \multirow[t]{2}{*}{$\mathrm{CD} 4+$ count cells $/ \mathrm{mm}^{3}$} & Normal & 11 & 61.1 & 10 & 83.3 & 1.693 & 0.193 \\
\hline & Low & 7 & 38.9 & 2 & 16.7 & & \\
\hline \multirow[t]{2}{*}{ CD8+ (\%) } & Normal & 18 & 100.0 & 11 & 91.7 & 1.552 & 0.213 \\
\hline & Low & 0 & 0.0 & 1 & 8.3 & & \\
\hline \multirow[t]{2}{*}{$\mathrm{CD} 8+$ count cells $/ \mathrm{mm}^{3}$} & Normal & 13 & 72.2 & 9 & 75.0 & 0.028 & 0.866 \\
\hline & Low & 5 & 27.8 & 3 & 25.0 & & \\
\hline \multirow[t]{2}{*}{ CD4/CD8 ratio } & Normal & 11 & 61.1 & 7 & 58.3 & 0.023 & 0.879 \\
\hline & Low & 7 & 38.9 & 5 & 41.7 & & \\
\hline \multirow[t]{2}{*}{ CD56+ (\%) } & Normal & 16 & 88.9 & 9 & 75.0 & 1.000 & 0.317 \\
\hline & Low & 2 & 11.1 & 3 & 25.0 & & \\
\hline \multirow[t]{2}{*}{ CD56+ count cells $/ \mathrm{mm}^{3}$} & Normal & 13 & 72.2 & 9 & 75.0 & 0.028 & 0.866 \\
\hline & Low & 5 & 27.8 & 3 & 25.0 & & \\
\hline \multirow[t]{2}{*}{ CD19+ (\%) } & Normal & 0 & 0 & 1 & 8.3 & 1.42 & 0.4 \\
\hline & Low & 18 & 100 & 11 & 91.7 & & \\
\hline \multirow[t]{2}{*}{ CD19+ count cells $/ \mathrm{mm}^{3}$} & Normal & 7 & 38.9 & 6 & 50 & 0.362 & 0.410 \\
\hline & Low & 11 & 61.1 & 6 & 50 & & \\
\hline \multirow[t]{2}{*}{ CD27+ (\%) } & Normal & 4 & 22.2 & 0 & 0 & 3.077 & 0.112 \\
\hline & Low & 14 & 77.8 & 12 & 100 & & \\
\hline
\end{tabular}

$C D$ cluster of differentiation, $\mathrm{mm}$ millimeter, $\mathrm{N}$ number, $\%$ percentage

did not have significant effect on the studied immunological parameters. The results of our study are indeed limited by the relatively short disease duration, lack of follow-up, inclusion of metabolically controlled cases, and absence of in vitro function tests and specific antibody response. Further studies are warranted on wider scale with assessment of patients during acidotic and non-acidotic phases of illness. Assessment of immune status in relation to the residual activity of the affected enzyme also could be worthwhile.

\section{Abbreviations}

ALC: Absolute lymphocyte count; ANC: Absolute neutrophil count; MMA: Methylmalonic acidemia; NK: Natural killer; PA: Propionic acidemia

\section{Acknowledgements}

Not applicable.

\section{Authors' contributions}

SMR, HSE, and RHE have put the study design and selection criteria of patients, supervised the data collection and statistical analysis, and performed the discussion of the results. They have also drafted the manuscript and revised it before publication. AMS and MAH have enrolled the patients, collected the data and arranged for laboratory testing, and collected the scientific material. All authors read and approved the final manuscript.

\section{Funding}

No funding was received.

\section{Availability of data and materials}

The datasets used and/or analyzed during the current study are available from the corresponding author on reasonable request.

\section{Ethics approval and consent to participate}

The study was conducted in accordance with the ethical standards of the Helsinki Declaration of 1964 as revised in 2008, and the study protocol gained approval from the local Ethical Committee of the Pediatric Department, Faculty of Medicine, Ain Shams University, REC-FAMSU (RHDIRB2019060201), Cairo, Egypt. This article does not contain any studies with animals performed by any of the authors.

Written informed consent was obtained from the caregivers of enrolled children before enrollment in the study, with preservation of patients' anonymity using documents and methods approved by the ethical review committee of the Faculty of Medicine, Ain-Shams University.

\section{Consent for publication}

Not applicable.

\section{Competing interests}

The authors declare that they have no competing interests. 


\section{Author details}

'Department of Pediatrics, Allergy and Immunology Unit, Faculty of Medicine, Children's Hospital, Ain-Shams University, Abbassya Square, Cairo 11566, Egypt. ${ }^{2}$ Genetics Unit, Children's Hospital, Ain-Shams University, Cairo, Egypt. ${ }^{3}$ Egyptian Ministry of Health Hospitals, Cairo, Egypt.

Received: 17 June 2019 Accepted: 5 August 2019

Published online: 06 September 2019

\section{References}

1. Zschocke J (2010) Disorders of Intermediary Metabolism. In: Hoffmann GF, Zschocke J Nyhan WL (eds.). Inherited Metabolic Diseases. Springer Heidelberg, Dordrecht, London, New York. p. 3-6. https://doi.org/10.1007/ 978-3-540-74723-9

2. Wong SN, Low LC, Lau YL, Nicholls J, Chan MY (1992) Immunodeficiency in methylmalonic acidemia. J Paediatr Child Health 28(2):180-183

3. Müller S, Falkenberg N, Mönch E, Jakobs C (1980) Propionic acidemia and immunodeficiency. Lancet 1(8167):551-552

4. Santos KD, Rocha M, Wannmacher CM, Wajner M (1996) The influence of organic acids on the proliferation of human peripheral lymphocytes activated by concanavalin A and pokeweed mitogen. Int j immunopharmacol 18(12):761-769

5. Alizadeh Najjarbashi F, Mesdaghi M, Alaei M, Shakiba M, Jami A, Ghadimi F (2015 Dec) A study on the humoral and complement immune system of patients with organic acidemia. Iran J Allergy Asthma Immunol 14(6):63864

6. Jeffrey Modell Foundation. 10 warning signs of primary immunodeficiency. URL: www.info4pi.org, last updated 2013, last visited 6, 2017.

7. WHO. Multicentre Growth Reference Study Group. WHO child growth standards. Available at: http://www.who.int/childgrowth/standards/ Technical_report.pdf. Last updated: 2006. Cited on: May 2015.

8. Huebner RE, Schein MF, Hall CA, Barnes SA (1994) Delayed-type hypersensitivity anergy in human immunodeficiency virus-infected persons screened for infection with Mycobacterium tuberculosis. Clin Infect Dis 19:26-32

9. Tosato F, Bucciol G, Pantano G, Putti MC, Sanzari MC, Basso G et al (2015) Lymphocytes subsets reference values in childhood. Cytometry A 87(1):81-85

10. Kardar G, Oraei M, Shahsavani M, Namdar Z, Kazemisefat G, Ashtiani MH et al (2012) Reference intervals for serum immunoglobulins IgG, IgA, IgM and complements C3 and C4 in Iranian healthy children. Iranian J Public Health 41(7):59-63

11. El Essa M, Rahbeeni Z, Jumaah S, Joshi S, Al Jishi E, Rashed MS et al (1998) Infectious complications of propionic acidemia in Saudia Arabia. Clin Genet 54(1):90-94

12. Fujisawa D, Nakamura K, Mitsubuchi H, Ohura T, Shigematsu Y, Yorifuji T et al (2013) Clinical features and management of organic acidemias in Japan. Journal of Human Genetics 58(12):769-774

13. Centers for Disease Control and Prevention (CDC). Tuberculosis, Fact sheets: BCG vaccine. Available at: https://www.cdc.gov/tb/publications/factsheets/ prevention/bcg.htm. Last updated on: September 12, 2016. Cited on: December 2017.

14. Sass JO, Hofmann M, Skladal D, Mayatepek E, Schwahn B, Sperl W (2004) Propionic acidemia revisited: a workshop report. Clin Pediatr (Phila) 43(9): 837-843

15. Church JA, Koch R, Shaw KN, Nye CA, Donnell GN (1984) Immune functions in methylmalonic aciduria. J Inherit Metab Dis 7(1):12-14

16. Hutchinson RJ, Bunnell K, Thoene JG (1985) Suppression of granulopoietic progenitor cell proliferation by metabolites of the branched-chain amino acids. J Pediatr 106(1):62-65

17. Reda SM, El-Owaidy RH, Lotfy N, El- Toukhy S (2017) Reliability of candida skin test in the evaluation of T-cell function in infancy. Egypt J Pediatr Allergy Immunol 15(1):25-30

18. Nelson KE, Speck SM, Suprasert S, Smith T (1984) A study of cellular immunity in clinically healthy children of parents with leprosy in northern Thailand. Int J Lepr Other Mycobact Dis 52(2):147-153

19. Ohri LK, Omaha N (2004) Pediatric case series evaluating a standardized Candida albicans skin test product. Ann Pharmacother 38(6):973-977
20. Schlottfeldt J, Blazina LR, Wannmacher CM, Wajner M (1995) The effect of organic acids on phytohaemagglutinin-activated proliferation of human lymphocytes in vitro. Int J Immuno-pharmacol 17(3):175-182

\section{Publisher's Note}

Springer Nature remains neutral with regard to jurisdictional claims in published maps and institutional affiliations.

\section{Submit your manuscript to a SpringerOpen ${ }^{\circ}$ journal and benefit from:}

- Convenient online submission

- Rigorous peer review

- Open access: articles freely available online

- High visibility within the field

- Retaining the copyright to your article

Submit your next manuscript at $\boldsymbol{\nabla}$ springeropen.com 